\title{
Pengaruh Edukasi Metode FGD (Focus Group Discussion) Terhadap Pengetahuan Swamedikasi Antipiretik di Kabupaten Pemalang
}

\author{
Ismiyatul Falakh $^{1 *}$, Wulan Agustin Ningrum ${ }^{2}$, Ainun Muthoharoh ${ }^{3}$, Yulian \\ Wahyu Permadi ${ }^{4}$ \\ 1,2,3,4 Sarjana Farmasi, Universitas Muhammadiyah Pekajangan Pekalongan, Indonesia \\ *email: ismifalakh@gmail.com
}

\begin{abstract}
Self-medication or self-medication in its implementation can be a source of medication errors due to limited public knowledge of drugs and their use. To minimize the occurrence of errors in self-medication is to provide education with the FGD method where this method provides an opportunity for group members to provide their opinions. The purpose of this study was to determine the effect and relationship of education using the FGD (Focus Group Discussion) method on knowledge of antipyretic self-medication. This research method is a quasiexperimental design with pretest and posttest with control group. Sampling used a random sampling technique, totaling 96 respondents from Sugihwaras Village and West Tegalsari Village who met the inclusion criteria. Data analysis used univariate and bivariate analysis. The results of the univariate analysis for the characteristics of the respondents mostly graduated from elementary school (85.4\%) and had jobs as fishermen and farmers, the source of information obtained in carrying out self-medication was based on personal or family experience $(68.8 \%)$. The results showed that most of the respondents who worked as fishermen and farmers, the level of knowledge before being given education was in the poor category, after being given education related to antipyretic self-medication, the level of knowledge of the respondents increased, namely in the good category. The conclusion in this study is that there is an influence and relationship between education with the FGD method on knowledge of antipyretic self-medication for fisherman workers and farmers.
\end{abstract}

Keywords: Antipyretics; FGDs; self-medication; knowledge level

\begin{abstract}
Abstrak
Swamedikasi atau pengobatan mandiri dalam pelaksanaannya dapat menjadi sumber terjadinya kesalahan pengobatan karena keterbatasan pengetahuan masyarakat akan obat dan penggunaannya. Untuk meminimalisir terjadinya kesalahan dalam swamedikasi adalah memberikan edukasi dengan metode FGD dimana metode ini memberikan kesempatan pada anggota grup untuk memberikan pendapatnya. Tujuan dalam penelitian ini untuk mengetahui pengaruh dan hubungan edukasi metode FGD (Focus Group Discussion) terhadap pengetahuan swamedikasi antipiretik. Metode penelitian ini adalah quasi eksperimental dengan rancangan pretest and postest with control group. Pengambilan sampel menggunakan teknik random sampling yang berjumlah 96 responden masyarakat Kelurahan Sugihwaras dan Desa Tegalsari Barat yang memenuhi kriteria inklusi. Analisis data menggunakan analisis univariat dan bivariat. Hasil analisis univariat untuk karakteristik responden sebagian besar berpendidikan akhir SD $(85,4 \%)$ dan memiliki pekerjaan sebagai nelayan dan petani, sumber informasi yang diperoleh dalam melakukan swamedikasi berdasarkan pengalaman pribadi atau keluarga $(68,8 \%)$. Hasil penelitian menunjukkan sebagian besar responden dengan pekerjaan nelayan dan petani tingkat pengetahuan sebelum diberikan edukasi termasuk dalam kategori kurang, setelah diberikan edukasi terkait swamedikasi antipiretik tingkat pengetahuan responden mengalami peningkatan yaitu dalam kategori baik. Kesimpulan pada penelitian ini terdapat pengaruh dan hubungan edukasi dengan metode FGD terhadap pengetahuan swamedikasi antipiretik pada pekerja nelayan dan petani.
\end{abstract}

Kata kunci: Antpiretik; FGD; swamedikasi; tingkat pengetahuan. 


\section{Prosiding Seminar Nasional Kesehatan 2021 Lembaga Penelitian dan Pengabdian Masyarakat Universitas Muhammadiyah Pekajangan Pekalongan}

\section{Pendahuluan}

Pengobatan sendiri atau swamedikasi (self-medication) adalah penggunaan obatobatan dengan maksud terapi tanpa saran dari profesional atau tanpa resep. Pengobatan sendiri termasuk memperoleh obat-obatan tanpa resep, membeli obat berdasarkan resep lama yang pernah diterima, berbagi obat-obatan dengan kerabat atau anggota lingkaran sosial seseorang atau menggunakan sisa obat-obatan yang disimpan dirumah (Harahap et al., 2017).

Hasil Riset Kesehatan Dasar tahun 2018 mencatat bahwa 50,7\% rumah tangga menyimpan obat untuk swamedikasi. Swamedikasi menjadi alternatif yang diambil masyarakat untuk meningkatkan keterjangkauan pengobatan. Pada pelaksanaannya swamedikasi dapat menjadi sumber terjadinya kesalahan pengobatan (medication error) karena keterbatasan pengetahuan masyarakat akan obat dan penggunaannya.

Pengetahuan terkait swamedikasi antipiretik sangat diperlukan karena efek samping yang ditimbulkan dalam penggunaan jangka waktu yang lama akan menyebabkan kelainan hati (IAI, 2014). Guna meminimalisir terjadinya kesalahan dalam swamedikasi antipiretik, salah satu usaha untuk mengurangi kesalahan dan penatalaksanaannya adalah dengan pemberian informasi kesehatan atau edukasi. Edukasi yang dapat dilakukan adalah dengan mtode FGD (Focus Group Discussion) karena dengan metode ini anggota grup diberi kesempatan dalam menyampaikan pendapatnya atau mendorong peserta untuk berkomunikasi satu dengan yang lain sehingga dapat menggali informasi mengenai pengetahuan tentang swamedikasi antipiretik (Moeliono, 2018). Oleh karena itu perlu dilakukan penelitian untuk mengetahui apakah ada pengaruh dan hubungan edukasi dengan metode FGD terhadap pengetahuan swamedikasi antipiretik.

Pada hasil penelitian Harahap et al (2017) menyebutkan bahwa tingkat pengetahuan dipengaruhi oleh pendidikan terakhir dan pekerjaan. Berdasarkan studi pendahuluan di Kelurahan Sugihwaras dan Desa Tegalsari Barat Kabupaten Pemalang, dari data monografi di Kelurahan Sugihwaras merupakan tipologi desa nelayan sehingga banyak masyarakat yang memiliki pekerjaan sebagai nelayan dengan tingkat pendidikan yang rendah. Sedangkan di Desa Tegalsari Barat dilihat dari data monografi merupakan tipologi desa persawahan sehingga banyak masyarakat yang memiliki pekerjaan sebagai petani dengan tingkat pendidikan yang rendah.

Dari latar belakang tersebut peneliti ingin melakukan penelitian terkait bagaimana pengaruh dan hubungan tingkat pengetahuan swamedikasi antipiretik terhadap edukasi dengan metode FGD di Kelurahan Sugihwaras dengan masyarakat yang memiliki pekerjaan sebagai nelayan dan Desa Tegalsari Barat dengan masyarakat yang memiliki pekerjaan sebagai petani, membuktikan pada hasil penelitian Harahap et al (2017) bahwa pendidikan terakhir dan pekerjaan mempengaruhi tingkat pengetahuan.

\section{Metode}

Jenis penelitian ini adalah quasi eksperimental dengan menggunakan rancangan penelitian pretest postest with control group. Penelitian di lakukan pada bulan April, bertempat di Kelurahan Sugihwaras dan Desa Tegalsari Barat Kabupaten Pemalang. Sampel yang digunakan adalah masyarakat Kelurahan Sugihwaras yang memiliki 


\section{Prosiding Seminar Nasional Kesehatan 2021 Lembaga Penelitian dan Pengabdian Masyarakat Universitas Muhammadiyah Pekajangan Pekalongan}

pekerjaan sebagai nelayan dan masyarakat Desa Tegalsari Barat yang memiiki pekerjaan sebagai petani yang yang masuk dalam kriteria inklusi yaitu berpendidikan rendah, usia 20-50 tahun, bukan tenaga kesehatan, bisa membaca dan menulis serta dapat bekerja sama dengan peneliti. Teknik sampling yang digunakan adalah random sampling dan jumlah sampel yang diambil sebanyak 96 responden yang dihasilkan menggunakan rumus Wibisono karena didasarkan pada pertimbangan bahwa populasi relatif besar dan tidak dapat teridentifikasi dengan pasti.

Alat pengumpulan data menggunakan kuesioner yang telah tervalidasi dan leaflet tentang swamedikasi antipiretik. Kuesioner swamedikasi antipiretik berjumlah 11 pernyataan dan skala pengukuran yang digunakan yaitu skala Guttman. Kuesoner ini disediakan jawaban "Benar" dan "Salah", dimana pada pernyataan favorable jawaban "Benar" diberi nilai 1 dan jawaban "Salah" diberi nilai 0. Pada pernyataan unfavorable jawaban "Benar" diberi nilai 0 dan jawaban "Salah" diberi nilai 1 . Data yang diperoleh dilakukan analisis univariat untuk melihat distribusi frekuensi masing-masing variabel, kemudian dilakukan analisis bivariat menggunakan uji wilcoxon dan mann whitney untuk mengetahui pengaruh dan hubungan edukasi dengan metode FGD terhadap pengetahuan swamedikasi antipiretik.

\section{Hasil dan Pembahasan}

\section{Hasil}

Penelitian ini dilakukan selama satu bulan dari tanggal 8 April - 7 Mei 2021 bertempat di Kelurahan Sugihwaras dan Desa Tegalsari Barat Kabupaten Pemalang. Analisis yang digunakan adalah analisis univariat untuk mengetahui distribusi frekuensi setiap variabel dan analisis bivariat untuk mengetahui pengaruh dan hubungan edukasi metode FGD terhadap pengetahuan swamedikasi antipiretik.

\section{Karakteristik Responden}

Karakteristik responden menunjukkan bahwa responden berjenis kelamin laki-laki $(6,5 \%)$, berusia $41-50$ tahun $(53,1 \%)$, pendidikan akhir SD $(85,4 \%)$, memiliki pekerjaan sebagai nelayan dan petani, jumlah pendapatan Rp. 500.000 - Rp. 1000.000 $(59,4 \%)$, sumber informasi melakukan swamedikasi berasal dari pengalaman pribadi atau keluarga $(68,8 \%)$, kegiatan yang diikuti kelompok nelayan dan kelompok tani sesuai pekerjaan, tidak memiliki pengalaman $(77,1 \%)$.

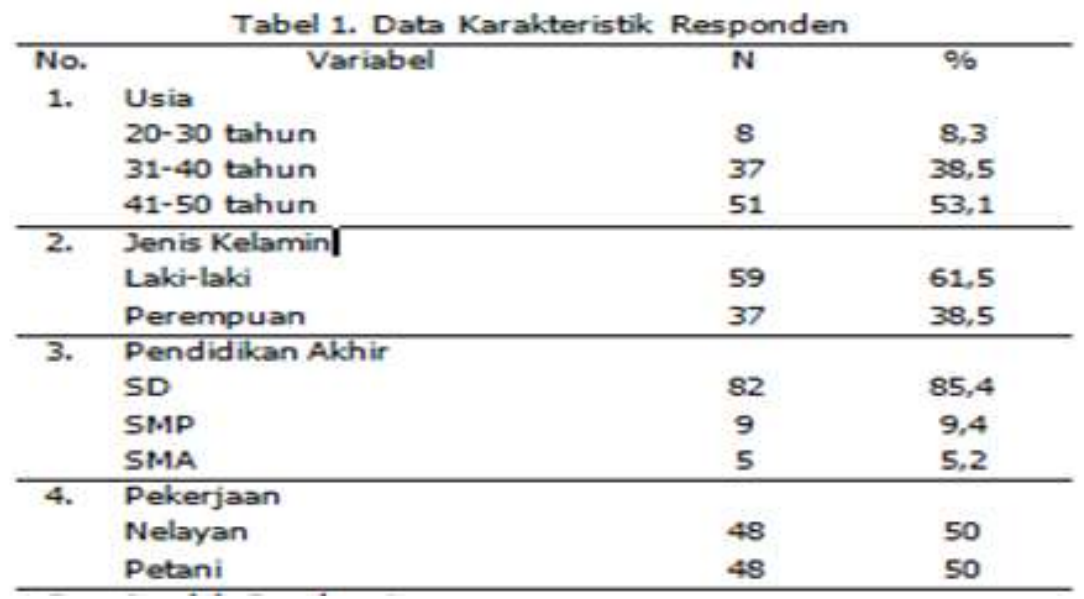




\section{Prosiding Seminar Nasional Kesehatan Lembaga Penelitian dan Pengabdian Masyarakat Universitas Muhammadiyah Pekajangan Pekalongan}

\begin{tabular}{|c|c|c|c|}
\hline No. & Variabel & $\mathbf{N}$ & $\%$ \\
\hline \multirow[t]{5}{*}{5.} & Jumlah Pendapatan & & \\
\hline & $<\mathrm{Rp} .500 .000$ & 35 & 36,5 \\
\hline & Rp. 500.000-Rp. 1.000 .000 & 57 & 59,4 \\
\hline & Rp. 1.000.000-Rp. 2.000.000 & 4 & 4,2 \\
\hline & $>$ Rp. 2.000.000 & 0 & 0 \\
\hline \multirow[t]{5}{*}{6.} & Sumber Informasi & & \\
\hline & Media massa & 3 & 3,1 \\
\hline & Teman dan tetangga & 27 & 28,1 \\
\hline & Pengalaman pibadi atau & 66 & 68,8 \\
\hline & keluarga & & \\
\hline \multirow[t]{4}{*}{7.} & Kegiatan yang dikkuti & & \\
\hline & PKK & 0 & 0 \\
\hline & Kelompok Nelayan & 48 & 50 \\
\hline & Kelompok Tani & 48 & 50 \\
\hline \multirow[t]{5}{*}{8.} & Pengalaman & & \\
\hline & Pelatihan/Workshop & 19 & 19,8 \\
\hline & Posyandu & 0 & 0 \\
\hline & Rawat inap & 3 & 3,1 \\
\hline & Tidak memiliki & 77 & 77,1 \\
\hline
\end{tabular}

\section{Tingkat Pengetahuan Responden tentang Swamedikasi Antipiretik}

Tingkat Pengetahuan Sebelum diberikan Edukasi

Tabel 2. Distribusi Frekuensi Kategori Pengetahuan Sebelum diberikan Edukasi

\begin{tabular}{lccccc}
\hline \multirow{2}{*}{ Kategori } & \multicolumn{2}{c}{ Nelayan } & & Total & $\%$ \\
\cline { 2 - 3 } & \multicolumn{2}{c}{ Eksperimen } & Kontrol & & \\
\hline Baik & 0 & 0 & & 0 & 0 \\
Cukup & 7 & 3 & & 10 & 20,84 \\
Kurang & 17 & 21 & & 38 & 79,16 \\
\hline \multicolumn{1}{c}{ Kategori } & \multicolumn{2}{c}{ Petani } & & Total & $\%$ \\
\cline { 2 - 3 } & \multicolumn{2}{c}{ Eksperimen } & Kontrol & & \\
\hline Baik & 0 & 0 & & 0 & 0 \\
Cukup & 5 & 4 & 9 & 18,75 \\
Kurang & 19 & 20 & 39 & 81,25 \\
\hline
\end{tabular}

Dari Tabel 2 dapat diketahui bahwa sebagian besar responden termasuk dalam kategori pengetahuan kurang yaitu $79,16 \%$ pada pekerja nelayan dan $81,25 \%$ pada pekerja petani. Sebelum diberikan edukasi tidak ada responden yang termasuk dalam kategori pengetahuan baik.

Tingkat Pengetahuan Sesudah diberikan Edukasi

Tabel 3. Distribusi Frekuensi Kategori Pengetahuan sesudah diberikan Edukasi

\begin{tabular}{lcccc}
\hline \multirow{2}{*}{ Kategori } & \multicolumn{2}{c}{ Nelayan } & Total & $\%$ \\
\cline { 2 - 4 } & Eksperimen & Kontrol & & \\
\hline Baik & 24 & 0 & 24 & 50 \\
Cukup & 0 & 7 & 7 & 14,58 \\
Kurang & 0 & 17 & Total & 35,42 \\
\hline \multicolumn{1}{c}{ Kategori } & \multicolumn{2}{c}{ Petani } & & $\%$ \\
\cline { 2 - 4 } & Eksperimen & Kontrol & & 50 \\
Baik & 24 & 0 & 6 & 17,5 \\
Kukup & 0 & 6 & 18 & 37,5 \\
\hline
\end{tabular}




\section{Prosiding Seminar Nasional Kesehatan Lembaga Penelitian dan Pengabdian Masyarakat Universitas Muhammadiyah Pekajangan Pekalongan}

Dari Tabel 3 dapat diketahui bahwa setelah diberikan edukasi pada kelompok eksperimen responden termasuk dalam kategori baik. Sedangkan pada kelompok kontrol tidak diberikan edukasi sehingga tidak ada peningkatan pengetahuan baik pada pekerja nelayan maupun pekerja petani.

\section{Pengaruh Edukasi Metode FGD Terhadap Pengetahuan Swamedikasi Antipiretik}

Tabel 4. Pengaruh Edukasi Metode FGD Terhadap Pengetahuan Swamedikasi Antipiretik Pada Pekerja Nelayan

\begin{tabular}{lccccccccc}
\hline \multirow{2}{*}{ Kelompok } & \multicolumn{6}{c}{ Kriteria sebelum edukasi } & \multicolumn{6}{c}{ Kriteria sesudah edukasi } & \multirow{2}{*}{ Sean } & Sig \\
\cline { 2 - 7 } & Baik & Cukup & Kurang & Baik & Cukup & Kurang & & \\
\hline Eksperimen & 0 & 7 & 17 & 24 & 0 & 0 & 12,50 & 0,000 \\
Kontrol & 0 & 3 & 21 & 0 & 7 & 17 & 8,55 & 0,040 \\
\hline Total \% & 0 & 20,84 & 79,16 & 50 & 14,58 & 35,42 & & \\
\hline
\end{tabular}

Pada Tabel 4 dapat dilihat hasil uji wilcoxon pada pekerja nelayan didapatkan bahwa terdapat pengaruh edukasi dengan metode FGD terhadap pengetahuan swamedikasi antipiretik pada kelompok eksperimen dengan nilai sig 0,000.

Tabel 5. Pengaruh Edukasi Metode FGD Terhadap Pengetahuan Swamedikasi Antipiretik Pada Pekerja Petani

\begin{tabular}{lccccccccc}
\hline \multirow{2}{*}{ Kelompok } & \multicolumn{2}{c}{ Kriteria sebelum edukasi } & \multicolumn{2}{c}{ Kriteria sesudah edukasi } & \multirow{2}{*}{ Mean } & Sig \\
\cline { 2 - 7 } & Baik & Cukup & Kurang & Baik & Cukup & Kurang & & \\
\hline Eksperimen & 0 & 5 & 19 & 24 & 0 & 0 & 12,50 & 0,000 \\
Kontrol & 0 & 4 & 20 & 0 & 6 & 18 & 4,50 & 0,157 \\
\hline Total \% & 0 & 18,75 & 81,75 & 50 & 12,5 & 37,5 & & \\
\hline
\end{tabular}

Pada Tabel 5 dapat dilihat hasil uji wilcoxon pada pekerja petani didapatkan bahwa terdapat pengaruh edukasi dengan metode FGD terhadap pengetahuan swamedikasi antipiretik pada kelompok eksperimen dengan nilai sig 0,000.

\section{Hubungan Edukasi Metode FGD Terhadap Pengetahuan Swamedikasi Antipiretik}

Tabel 6. Hubungan Edukasi Metode FGD Terhadap Pengetahuan Swamedikasi Antipiretik

\begin{tabular}{clccccc}
\hline \multirow{3}{*}{ Pekerja } & Kategori & \multicolumn{2}{c}{$\begin{array}{c}\text { Kelompok } \\
\text { eksperimen }\end{array}$} & \multicolumn{2}{c}{$\begin{array}{c}\text { Kelompok } \\
\text { kontrol }\end{array}$} & \multirow{2}{*}{ Sig } \\
\cline { 2 - 6 } & & $\mathrm{N}$ & $\%$ & $\mathrm{~N}$ & $\%$ & \\
\cline { 2 - 6 } Nelayan & Baik & 24 & 50 & 0 & 0 & \multirow{6}{*}{ Petani } \\
& Cukup & 0 & 0 & 7 & 14,58 & 0,000 \\
& Kurang & 0 & 0 & 17 & 35,42 & \\
& Baik & 24 & 50 & 0 & 0 & \multirow{2}{*}{0,000} \\
& Cukup & 0 & 0 & 6 & 12,5 & \\
& Kurang & 0 & 0 & 16 & 37,5 & \\
\hline
\end{tabular}




\section{Prosiding Seminar Nasional Kesehatan Lembaga Penelitian dan Pengabdian Masyarakat Universitas Muhammadiyah Pekajangan Pekalongan}

Pada Tabel 6 dapa dilihat bahwa terdapat hubungan yang signifikan antara edukasi dengan metode FGD terhadap pengetahuan swamedikasi antipiretik dengan nilai $\operatorname{sig} 0,000$ baik pada pekerja nelayan maupun petani.

\section{Pembahasan}

\section{Karakteristik Responden}

Berdasarkan Tabel 1 dapat diketahui data karakteristik umum responden bahwa sebagian besar berusia 41-50 tahun sebanyak 51 responden dengan persentase $53,1 \%$. Berdasarkan hasil data tersebut, sebagian besar responden termasuk dalam kategori usia dewasa. Usia dewasa merupakan semua orang yang berusia $\geq 18$ tahun yang telah dianggap memiliki kapasitas untuk membuat suatu keputusan terhadap kesehatan individu dan bertanggung jawab terhadap keputusan yang telah dibuat tersebut (Sketcher-Baker, 2017). Menurut Notoatmodjo (2014) apabila usia seseorang semakin bertambah maka tingkat pengetahuan akan berkembang sesuai pengalaman, tetapi pada penerimaan informasi akan berkurang karena fungsi otak menurun.

Tingkat pendidikan akhir responden lebih dari sebagian besar memiliki tingkat pendidikan akhir SD sebanyak 82 responden dengan persentase $85,4 \%$. Hasil ini sesuai dengan penelitian Syarifah et al (2020) dimana responden lebih banyak yang memiliki pendidikan akhir SD. Masyarakat yang berpendidikan rendah maka memiliki pengetahuan yang rendah terhadap swamedikasi, sehingga memilih berobat ke dokter. Sedangkan masyarakat yang berpendidikan tinggi lebih memahami swamedikasi sehingga mereka mampu melakukan swamedikasi sesuai gejala dan penyakitnya tanpa konsultasi ke dokter.

Karakteristik umum responden menunjukkan bahwa terdapat dua pekerjaan yaitu sebagai nelayan dan petani. Menurut Notoatmodjo (2012) jenis pekerjaan juga merupakan faktor yang dapat mempengaruhi pengetahuan seseorang terhadap swamedikasi. Seseorang yang memiliki pekerjaan dalam bidang kesehatan akan memilih pengobatan yang lebih rasional karena memiliki pengetahuan yang baik dibandingkan dengan seseorang yang memiliki pekerjaan diluar bidang kesehatan akan memiliki pola pikir yang berbeda terkait swamedikasi (Rikomah, 2016).

Karakteristik umum responden menunjukkan bahwa sebagian besar sumber informasi yang telah didapatkan untuk melakukan swamedikasi berdasarkan pengalaman pribadi atau keluarga sebanyak 66 responden dengan persentase $68,8 \%$. Hasil yang diperoleh tersebut sesuai dengan penelitian yang dilakukan oleh Harahap (2017) yaitu mayoritas responden melakukan swamedikasi berdasarkan informasi dari pengalaman pribadi atau keluarga.

\section{Tingkat Pengetahuan Responden Tentang Swamedikasi Antipiretik}

Tingkat pengetahuan pada pekerja nelayan dan petani mengenai swamedikasi antipiretik sebelum diberikan edukasi sebagianbesar responden memliki kategori pengetahuan kurang. Pengetahuan yang kurang tersebut mungkin terjadi karena belum diberikannya informasi terkait swamedikasi antipiretik sehingga pengeahuan responden masih dalam kategori kurang. 


\section{Prosiding Seminar Nasional Kesehatan 2021 Lembaga Penelitian dan Pengabdian Masyarakat Universitas Muhammadiyah Pekajangan Pekalongan}

Tingkat pengetahuan setelah diberikan edukasi mengenai swamedikasi antipiretik pada pekerja nelayan dan petani mengalami peningkatan pada kategori baik. Pemberian edukasi terkait swamedikasi antipiretik dilakukan dengan mentode FGD (Focus Group Discussion). Metode FGD ini merupakan sebuah usaha menggunakan interaksi kelompok untuk menghasilkan data dan peserta bersifat aktif sehingga memiliki kesempatan berdiskusi menyampaikan pendapatnya dan bebagi pengalaman dengan peserta lain (Moeliono, 2018).

Pada kelompok eksperimen baik pada pekerja nelayan maupun petani mengalami peningkatan pengetahuan. Karakteristik responden dapat mempengaruhi adanya peningkatan pengetahuan tersebut, yaitu usia responden 20-50 tahun, pendidikan, pekerjaan, pengalaman, informasi, sosial budaya, lingkungan dan ekonomi (Budiman, 2013).

\section{Pengaruh Edukasi Metode FGD Terhadap Pengetahuan Swamedikasi Antipiretik}

Pengaruh edukasi dengan metode FGD (Focus Group Discussion) terhadap tingkat pengetahuan swamedikasi antipiretik dapat dilihat dari nilai pretest dan postest pada masing-masing kelompok. Berdasarkan Tabel 4 dapat dilihat dari hasil uji wilcoxon pada pekerja nelayan menunjukkan nilai sig 0,000 pada kelompok eksperimen dimana nilai sig tersebut $<0,05$ sehingga dapat dikatakan bahwa terdapat pengaruh edukasi metode FGD terhadap pengetahuan swamedikasi antipiretik. Sedangkan pada kelompok kontrol dihasilkan nilai sig 0,040<0,05, namun nilai sig tersebut tidak diartikan terdapat pengaruh dari edukasi dengan metode FGD karena pada kelompok kontrol tidak diberikan intervensi atau edukasi. Adanya pengaruh pada kelompok kontrol dapat dikarenakan adanya keraguan responden dalam menjawab kuesioner pretest dan postest sehingga terdapat perbedaan nilai pretest dan postest.

Berdasarkan Tabel 5 dapat dilihat hasil uji wilcoxon pada pekerja petani menunjukkan nilai sig 0,000 pada kelompok eksperimen dimana nilai sig tersebut $<0,05$ sehingga dapat dikatakan bahwa terdapat pengaruh edukasi metode FGD terhadap pengetahuan swamedikasi antipiretik. Pada kelompok kontrol dihasilkan nilai sig 0,157>0,05 sehingga tidak terdapat pengaruh edukasi dengan metode FGD karena pada kelompok kontrol tidak diberikan edukasi mengenai swamedikasi antipiretik.

\section{Hubungan Edukasi Metode FGD Terhadap Pengetahuan Swamedikasi Antipiretik}

Berdasarkan Tabel 6 dapat diketahui bahwa nilai sig yang diperoleh adalah 0,000 pada kelompok nelayan maupun petani, dimana nilai sig $0,000<0,05$. Sehingga dapat diketahui bahwa terdapat hubungan edukasi dengan metode FGD (Focus Group Discussion) terhadap pengetahuan swamedikasi antipiretik baik pada pekerja nelayan maupun petani. Hasil penelitian ini sejalan dengan penelitian Rizki (2012) bahwa metode FGD dapat meningkatkan pengetahuan remaja terkait kesehatan reproduksi. Pada penelitian Adifta dan Bayu (2016) tentang perbedaan efektivitas penyuluhan kesehatan reproduksi antara metode ceramah dan FGD menyebutkan bahwa metode FGD lebih efektif untuk meningkatkan pengetahuan dan sikap terkait kesehatan 


\section{Prosiding Seminar Nasional Kesehatan Lembaga Penelitian dan Pengabdian Masyarakat Universitas Muhammadiyah Pekajangan Pekalongan}

reproduksi dibandingkan dengan metode ceramah. Menurut penelitian Lathifah et al (2015) tentang Perbandingan Metode CBIA dan FGD dalam Peningkatan Pengetahuan dan Ketepatan Caregiver dalam Upaya Swamedikasi Demam pada Anak juga menyebutkan bahwa metode FGD lebih baik dalam meningkatkan pengetahuan dibandingkan dengan metode CBIA. Dalam metode FGD (Focus Group Discussion) peserta bersifat aktif dan memiliki kesempatan berdiskusi menyampaikan pendapatnya dan berbagi pengalaman dengan peserta lain. Sehingga dari kelebihan penggunaan metode edukasi FGD tersebut responden lebih mudah dalam menerima informasi yang telah diberikan dan meningkatkan pengetahuan terkait swamedikasi antipiretik.

\section{Kesimpulan}

Berdasarkan Penelitian menunjukkan bahwa terdapat peningkatan pengetahuan swamedikasi antipiretik setelah diberikan edukasi dari kategori kurang menjadi kategori baik pada pekerja nelayan maupun petani. Terdapat hubungan edukasi dengan metode FGD (Focus Group Discussion) terhadap pengetahuan swamedikasi antipiretik baik pada pekerja nelayan maupu petani dengan masing-masing nilai $p$-value $=0,000$.

\section{Referensi}

[1] Budiman, \&. A, "Kapita Selekta Kuesioner: Pengetahuan dan Sikap dalam Penelitian Kesehatan," Jakarta: Salemba Medika, 2013.

[2] Ikatan Apoteker Indonesia, "Informasi Spesialite Obat Indonesia Volume 49," Jakarta: PT ISFI Penerbitan, 2014.

[3] K. Sketcher-Baker, "Guide to Informed Decision-Making in Health Care $2^{\text {nd }}$ Ed," Queenslad Health, 09, 67, 2017

[4] L. Moeliono, "Focus Group Discussion, Edisi Revisi," Jakarta: Universitas Atma Jaya, 2018.

[5] M. Lathifah, Susanti, \& Wibowo, M. I, "Perbandingan Metode CBIA dan FGD dalam Peningkatan Pengetahuan dan Ketepatan Caregiver dalam Upaya Swamedikasi Demam Pada Anak,"Pharm. Sci. Res., Vol. 2 No. 2, pp. 89-100, 2015, doi: 10.7454/psr.v2i2.3336

[6] N. A. Harahap, K. Khairunnisa, and J. Tanuwijaya, "Patient knowledge and rationality of self-medication in three pharmacies of Panyabungan City, Indonesia," J. Sains Farm. Klin., vol. 3, no. 2, p. 186, 2017, doi: 10.29208/jsfk.2017.3.2.124.

[7] N. Rizki, "Metode Focus Group Discussion dan Simulation Game Terhadap Peningkatan Pengetahuan Kesehatan Reproduksi," Kemas., vol. 8, no. 1, pp. 23-29, 2012.

[8] N. Syarifah, W. A. Ningrum, and N. Zuhana, "Tingkat Pengetahuan dan Sikap Terhadap Tindakan Pengobatan Mandiri Penyakit Kutu Air Level of Knowledge and Attitude Towards Self-Treatment Action of Water Flea Disease," no. 8, pp. $1-8,2020$. 


\section{Prosiding Seminar Nasional Kesehatan Lembaga Penelitian dan Pengabdian Masyarakat Universitas Muhammadiyah Pekajangan Pekalongan}

[9] S. Notoatmodjo, "Promosi Kesehatan dan Perilaku Kesehatan," Jakarta: Rineka Cipta, 2012.

[10] S. Notoatmodjo, "IImu Perilaku Kesehatan," Jakarta: Rineka Cipta, 2014.

[11] S. Rikomah, "Farmasi Klinik, Edisi 1," Yogyakarta: Deepublish, 2016. 